\title{
Impact of exogenous maltogenic a-amylase and maltotetraogenic amylase on sugar release in wheat bread
}

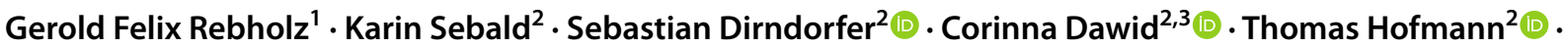 \\ Katharina Anne Scherf ${ }^{1,4}$ (1)
}

Received: 7 January 2021 / Revised: 9 March 2021 / Accepted: 12 March 2021 / Published online: 26 March 2021

(c) The Author(s) 2021

\begin{abstract}
The use of exogenous maltogenic $\alpha$-amylases or maltotetraogenic amylases of bacterial origin is common in wheat bread production, mainly as antistaling agents to retard crumb firming. To study the impact of maltogenic $\alpha$-amylase and maltotetraogenic amylase on straight dough wheat bread, we performed a discovery-driven proteomics approach with commercial enzyme preparations and identified the maltotetraogenic amylase P22963 from Pelomonas saccharophila and the maltogenic $\alpha$-amylase P19531 from Geobacillus stearothermophilus, respectively, as being responsible for the amylolytic activity. Quantitation of mono-, di- and oligosaccharides and residual amylase activity in bread crumb during storage for up to $96 \mathrm{~h}$ clarified the different effects of residual amylase activity on the sugar composition. Compared to the control, the application of maltogenic $\alpha$-amylase led to an increased content of maltose and especially higher maltooligosaccharides during storage. Residual amylase activity was detectable in the breads containing maltogenic $\alpha$-amylase, whereas maltotetraogenic amylase only had a very low residual activity. Despite the residual amylase activities and changes in sugar composition detected in bread crumb, our results do not allow a definite evaluation of a potential technological function in the final product. Rather, our study contributes to a fundamental understanding of the relation between the specific amylases applied, their residual activity and the resulting changes in the saccharide composition of wheat bread during storage.
\end{abstract}

Keywords Bread · Discovery-driven proteomics $\cdot$ Enzyme activity $\cdot$ Maltogenic $\alpha$-amylase $\cdot$ Maltotetraogenic amylase $\cdot$ Wheat

Katharina Anne Scherf

katharina.scherf@kit.edu

1 Leibniz-Institute for Food Systems Biology at the Technical University of Munich, Lise-Meitner-Str. 34, 85354 Freising, Germany

2 Chair of Food Chemistry and Molecular Sensory Science, TUM School of Life Sciences, Technical University of Munich, Lise-Meitner-Str. 34, 85354 Freising, Germany

3 Bavarian Center for Biomolecular Mass Spectrometry, Technical University of Munich, Gregor-Mendel-Str. 4, 85354 Freising, Germany

4 Department of Bioactive and Functional Food Chemistry, Institute of Applied Biosciences, Karlsruhe Institute of Technology (KIT), Adenauerring 20 a, 76131 Karlsruhe, Germany

\section{Introduction}

Wheat bread can be considered as an unstable multiphase food matrix subject to changes during storage: the flavor of fresh bread and the crispiness of the bread crust decrease, whereas crumb firmness and crumbliness increase. The changes in the bread crumb, also known as staling, lead to a loss of resilience and to firming [1], caused by water immobilization and redistribution processes. The retrogradation of amylopectin during storage immobilizes water, which leads to a decrease in freezable water in the bread crumb [2]. Furthermore, water redistribution occurs via water migration from gluten to starch and from crumb to crust. These migration patterns lead to an additional decrease in freezable water and to an increase in crumb firmness [3, 4]. Wheat starch rearrangements play the leading role in crumb firming. Amylose gelation occurs within hours, whereas that of amylopectin takes several days and involves reorganization of amylopectin side chains to form tightly 
packed double-helical structures. During storage, the amorphous gelatinized starch network present in fresh bread is transformed first into a partly crystalline state and then to a mostly continuous rigid crystalline starch network $[3,5,6]$.

Amylases can be added during bread production as antistaling agents [7]. Maltotetraogenic amylases and maltogenic $\alpha$-amylases are most commonly described as efficient antistaling agents in bread making [6, 8]. Maltotetraogenic amylase from Pelomonas saccharophila hydrolyzes $\alpha$ - $(1 \rightarrow 4)$-D-glucosidic bonds to remove successive maltotetraose residues from the non-reducing ends. It mainly acts on amylopectin, thus reducing amylopectin side chain rearrangement and crystallization $[9,10]$. Maltogenic $\alpha$-amylase from Geobacillus stearothermophilus successively cleaves $\alpha$-maltose units from the non-reducing ends of amylose and amylopectin. In comparison to maltotetraogenic amylase, it has a smaller effect on the molecular weight of the starch polymers and degrades the amylopectin molecules relatively slowly $[8,10]$. However, the enzyme reduces the molecular weight of amylose and thus, enhances amylose mobility and network formation [5]. This results in a greater initial firmness of breads manufactured with maltogenic $\alpha$-amylase $[11,12]$. The main influence on bread firming caused by maltogenic $\alpha$-amylase is due its subsequent cleavage along the side chains of the amylopectin molecules. They become too short to crystallize and the formation of a permanent amylopectin network during storage is inhibited $[8,10]$. Despite the initial increase in crumb firmness, this leads to a substantial delay in crumb firming [12].

An additional antistaling effect of maltotetraogenic and maltogenic $\alpha$-amylases may result from their ability to increase dextrin levels in wheat bread. Dextrins hinder the crystallization of amylopectin helices and may increase relative crumb humidity. However, compared to the hydrolytic effect on the starch polymers, the antistaling effect of dextrins is described to be of minor importance [13]. Maltotetraogenic amylase from P. saccharophila and maltogenic $\alpha$-amylase from $G$. stearothermophilus have a temperature optimum at approximately $60^{\circ} \mathrm{C}$ [14]. Several studies showed that both enzymes have a high temperature stability, whereby it is accepted that G. stearothermophilus maltogenic $\alpha$-amylase has a higher temperature stability and can be still active in wheat bread crumb after baking $[8,15$, 16]. It is unknown whether this activity is associated with an additional antistaling effect during storage of bread. In the following, residual activity means the amylolytic activity measured using enzymatic assays after extraction from baked bread crumb. To gain a better understanding of the effects of maltogenic $\alpha$-amylase and maltotetraogenic amylase in wheat bread making, it is necessary to study the formulation of the specific preparations as well as the impact of the preparations on sugar release during bread storage. Thus, a combined analytical approach has to be implemented to focus on the different relevant parameters in amylase preparations and wheat bread.

The use of enzymes in food production is defined in the European Union by the Regulation (EC) no. 1332/2008 and has to be in line with the Regulation (EU) no. 1169/2011 on the provision of food information to consumers $[17,18]$. According to these regulations, enzymes used as processing aids do not have to be labeled, because they are not classified as food ingredients of technological relevance in the final product. However, only in case this potential residual activity would have a functional effect in the final product, it would have to be labeled $[17,18]$.

The aim of our work was to characterize the protein composition of commercial amylase preparations commonly used in bread making and to elucidate their impact on the formation of sugars in the bread crumb during storage. In the first step, we identified and quantitated the amylase compared to other proteins in the preparation. Then we monitored sugar concentrations in wheat bread crumb during storage for up to $96 \mathrm{~h}$ and combined this with the quantitation of residual amylase activity. This approach allowed us to detect changes caused by a residual amylolytic activity in straight dough wheat bread.

\section{Materials and methods}

\section{Chemicals and flours}

All chemicals and solvents were HPLC-grade or higher. Water was deionized and purified using an Arium $611 \mathrm{VF}$ water purification system (Sartorius, Goettingen, Germany). Trypsin (from bovine pancreas, TPCKtreated, $\geq 10,000 \mathrm{BAEE} \mathrm{U/mg} \mathrm{protein),} \mathrm{sodium} \mathrm{hydroxide}$ solution (50-52\%; eluent for IC) and anhydrous sodium acetate $(\geq 99 \%)$ were from Sigma-Aldrich (Steinheim, Germany). $\alpha$-Amylase assay reagent (4-nitrophenyl $\alpha$-Dmaltoheptaoside (blocked), plus excess $\alpha$-glucosidase and glucoamylase) and $\beta$-amylase assay reagent (4-nitrophenyl $\beta$-D-maltotrioside, plus excess thermostable $\beta$-glucosidase) were purchased from Megazyme (Bray, Ireland). D- $(+)$-Glucose ( $\geq 99.5 \%)$, D-(-)-fructose ( $\geq 99 \%)$, sucrose $(\geq 99.5 \%)$, maltose monohydrate $(\geq 99 \%)$, maltotriose $(\geq 90 \%)$ and maltoheptaose $(\geq 70 \%)$ were from Sigma-Aldrich; maltotetraose $(\geq 97 \%)$, maltopentaose $(\geq 90 \%)$, maltohexaose $(\geq 95 \%)$ and maltooctaose $(\geq 80 \%)$ from Santa Cruz (Dallas, USA). Wheat flour type 550, according to the German flour classification system, was provided by Rosenmühle (Ergolding, Germany). 


\section{Amylase preparations}

Seven different commercial amylase preparations commonly applied in wheat bread making were used (Table 1). Two of them, (I) and (II), contained maltotetraogenic amylase (EC 3.2.1.60) from $P$. saccharophila. The maltogenic $\alpha$-amylase (EC 3.2.1.133) in the preparations (III), (IV), (V), (VI), and (VII) was from $G$. stearothermophilus.

\section{Determination of maltotetraogenic amylase activity}

The extraction of amylases for the activity assays was performed according to Cornaggia et al. [19]. In total, $1.0 \mathrm{~g}$ of dry matter of amylase preparation or bread was extracted with $10 \mathrm{~mL}$ of extraction buffer $(0.1 \mathrm{~mol} / \mathrm{L}$ sodium maleate, $\mathrm{pH} 5.5,1.0 \mathrm{mg} / \mathrm{mL}$ bovine serum albumin, $0.025 \mathrm{~mol} / \mathrm{L}$ dithiothreitol (DTT)) for $16 \mathrm{~h}$ at $22^{\circ} \mathrm{C}$. Then, centrifugation $\left(2500 \times g ; 20^{\circ} \mathrm{C} ; 10 \mathrm{~min}\right)$ and filtration $(0.45 \mu \mathrm{m}$; cellulose acetate filters) were performed.

The activity of maltotetraogenic amylase was determined using the Ceralpha method (Megazyme). The assay procedure was carried out as described by the manufacturer, except that the incubation time was extended to $60 \mathrm{~min}$ at $40{ }^{\circ} \mathrm{C}$ for the assay reaction. Quantitation of 4-nitrophenol was conducted by means of external calibration with a standard solution containing 4-nitrophenol dissolved and diluted with $1.5 \mathrm{~mL}$ of $20 \%$ (w/v) tri-sodium phosphate buffer ( $\mathrm{pH}$ 11). Maltotetraogenic amylase activity was reported in nkat/ $\mathrm{g}_{\mathrm{dm}}$. One kat is defined as the amount of 4-nitrophenol in mol released from the substrate non reducing-end blocked 4-nitrophenylmaltoheptaoside in one second under the assay conditions. All determinations were performed with three technical replicates.

Table 1 Composition of the bacterial amylase preparations and dosage recommendation as indicated by the manufacturer, activity of the amylase added to the dough in the baking experiments, residual

\section{Determination of maltogenic $a$-amylase activity}

The extraction of maltogenic $\alpha$-amylase was carried out as described above according to Cornaggia et al. [19]. Then the betamyl-3 method (Megazyme) was used to determine maltogenic $\alpha$-amylase activity. The amylase extract was diluted in an appropriate ratio with $0.1 \mathrm{~mol} / \mathrm{L} 2-(N$-morpholino)ethanesulfonic acid buffer $(\mathrm{pH}$ 6.2) containing $0.01 \mathrm{~mol} / \mathrm{L}$ ethylenediaminetetraacetic acid and $1.0 \mathrm{mg} / \mathrm{mL}$ bovine serum albumin. For the assay procedure, the incubation time of the extract and the substrate was set to $20 \mathrm{~min}$ at $40{ }^{\circ} \mathrm{C}$. The following procedure was performed exactly as described by the kit manufacturer. Quantitation of 4-nitrophenol was performed by means of external calibration with a standard solution containing 4-nitrophenol dissolved and diluted in $1 \%(\mathrm{w} / \mathrm{v})$ tris(hydroxymethyl)aminomethane (Tris)-buffer ( $\mathrm{pH} 8.5)$. Amylase activity was expressed in $\mathrm{nkat} / \mathrm{g}_{\mathrm{dm}}$. One kat is defined as the amount of 4-nitrophenol in mol released from the substrate non reducing-end blocked 4-nitrophenyl- $\beta$-D-maltotrioside in $1 \mathrm{~s}$ under the assay conditions. All determinations were performed with three technical replicates.

\section{Extraction of enzymes from the amylase preparations and determination of the protein content}

For ultra high-performance liquid chromatography time-offlight mass spectrometry (UHPLC-TOF-MS) analysis, the amylases were extracted from the preparations as described by Uhr et al. [20]. Each sample (0.5 $\mathrm{g}$ of dry matter) was extracted using $5.0 \mathrm{~mL}$ of extraction buffer $(0.1 \mathrm{~mol} / \mathrm{L}$ ammonium bicarbonate, $4.0 \mathrm{~mol} / \mathrm{L}$ urea and $0.005 \mathrm{~mol} / \mathrm{L}$ DTT, $\mathrm{pH} 8.0$, in water). The extraction was carried out at

activity in the bread crumb and relative residual activity based on the activity added to the dough

\begin{tabular}{|c|c|c|c|c|c|c|c|c|}
\hline \multirow[t]{2}{*}{ Preparation } & \multirow[t]{2}{*}{ Enzyme } & \multirow[t]{2}{*}{ EC number } & \multirow[t]{2}{*}{ Other ingredients } & \multirow{2}{*}{$\begin{array}{l}\text { Dosage } \\
\text { (mg/ } \\
\mathrm{kg} \text { of } \\
\text { flour) }\end{array}$} & \multirow{2}{*}{$\begin{array}{l}\text { Activity } \\
\text { (nkat/ } \\
\left.\mathrm{g}_{\mathrm{dm}}\right)\end{array}$} & \multicolumn{3}{|c|}{ Residual activity } \\
\hline & & & & & & $\left(\right.$ nkat $\left./ \mathrm{g}_{\mathrm{dm}}\right)$ & Mean $(\%)$ & Range (\%) \\
\hline (I) & Maltotetraogenic amylase & 3.2 .1 .60 & Sodium chloride, wheat starch & 850 & 85.8 & $0.9 \pm 0.3$ & 1.1 & $0.6-1.4$ \\
\hline (II) & Maltotetraogenic amylase & 3.2 .1 .60 & $\begin{array}{l}\text { Sodium chloride, wheat starch, } \\
\text { microcrystalline cellulose }\end{array}$ & 300 & 31.7 & $0.6 \pm 0.2$ & 1.9 & $1.2-2.9$ \\
\hline (III) & Maltogenic $\alpha$-amylase & 3.2 .1 .133 & Wheat flour, sodium chloride & 100 & 22.0 & $9.3 \pm 1.4$ & 42.3 & $38.0-47.7$ \\
\hline (IV) & Maltogenic $\alpha$-amylase & 3.2 .1 .133 & Maltodextrin, sodium chloride & 100 & 43.0 & $11.0 \pm 5.3$ & 25.7 & $11.3-35.7$ \\
\hline (V) & Maltogenic $\alpha$-amylase & 3.2 .1 .133 & $\begin{array}{l}\text { Maltodextrin, sodium chloride, } \\
\text { sunflower oil }\end{array}$ & 100 & 38.6 & $11.0 \pm 5.0$ & 28.6 & $18.5-43.9$ \\
\hline (VI) & Maltogenic $\alpha$-amylase & 3.2 .1 .133 & Wheat flour, sodium chloride & 100 & 31.5 & $14.3 \pm 3.8$ & 45.5 & $36.3-51.0$ \\
\hline (VII) & Maltogenic $\alpha$-amylase & 3.2 .1 .133 & $\begin{array}{l}\text { Maltodextrin, sodium chloride, } \\
\text { sunflower oil }\end{array}$ & 50 & 41.0 & $5.7 \pm 1.2$ & 13.9 & $11.9-15.0$ \\
\hline
\end{tabular}

$\mathrm{dm}$, based on dry matter, values are given as means $(n=3) \pm$ standard deviation 
room temperature by stirring for $30 \mathrm{~min}$. The extract was centrifuged $\left(20 \mathrm{~min} ; 20{ }^{\circ} \mathrm{C} ; 3750 \times g\right)$ and the supernatant was collected for further analysis. To optimize the conditions for the tryptic digest of extracts, the protein contents were quantified via a RP-HPLC method with UV detection at $210 \mathrm{~nm}$ as described earlier [21].

\section{Sample preparation, tryptic digest, and peptide clean-up}

The supernatant of the enzyme extracts was diluted in an appropriate volume to a protein concentration of $0.5 \mathrm{mg}$ / $\mathrm{mL}$ in $0.3 \mathrm{~mL}$ and $0.1 \mathrm{~mL}$ Tris- $\mathrm{HCl}(1.5 \mathrm{~mol} / \mathrm{L})$ and $0.1 \mathrm{~mL}$ 1-propanol were added. Reduction was performed by adding tris(2-carboxyethyl)phosphine solution $(0.05 \mathrm{~mol} / \mathrm{L}$ tris $(2-$ carboxyethyl)phosphine in $0.5 \mathrm{~mol} / \mathrm{L}$ Tris- $\mathrm{HCl}, \mathrm{pH} 8.5$ ) and incubation for $30 \mathrm{~min}$ at $60^{\circ} \mathrm{C}$. Alkylation of cysteine residues was performed for $45 \mathrm{~min}$ at $37{ }^{\circ} \mathrm{C}$ in the dark using $0.1 \mathrm{~mL}$ chloroacetamide solution $(0.5 \mathrm{~mol} / \mathrm{L}$ chloroacetamide in $0.5 \mathrm{~mol} / \mathrm{L}$ Tris- $\mathrm{HCl}, \mathrm{pH} 8.5$ ). Then the samples were dried using a rotary vacuum concentrator $\left(37^{\circ} \mathrm{C}, 3 \mathrm{~h}\right.$, $800 \mathrm{~Pa}$ ). For protein hydrolysis, the samples were reconstituted in $0.5 \mathrm{~mL}$ of trypsin stock solution with a trypsin-tosubstrate ratio of $1: 20(\mathrm{w} / \mathrm{w})(0.04 \mathrm{~mol} / \mathrm{L}$ urea in $0.1 \mathrm{~mol} / \mathrm{L}$ Tris- $\mathrm{HCl}, \mathrm{pH} 7.8$ ) and incubated at $37{ }^{\circ} \mathrm{C}$ for $16 \mathrm{~h}$. The hydrolysis was stopped by heating the samples at $95{ }^{\circ} \mathrm{C}$ for $8 \mathrm{~min}$. The peptide mixture was cleaned by solid phase extraction (SPE) using $100 \mathrm{mg}$ Discovery DSC-18 tubes (Merck, Darmstadt, Germany). The tubes were activated with methanol (1 mL), equilibrated with acetonitrile/water/ formic acid (FA) $(80: 20: 0.1 ; 1 \mathrm{~mL})$ and washed with acetonitrile/water/FA $(2: 98: 0.1 ; 5 \times 1 \mathrm{~mL})$. Having loaded the samples, the cartridges were washed again $(5 \times 1 \mathrm{~mL})$. The peptides were eluted with acetonitrile/water/FA (40:60:0.1) and dried using a rotary vacuum concentrator $\left(37^{\circ} \mathrm{C}, 4 \mathrm{~h}\right.$, $800 \mathrm{~Pa}$ ). For UHPLC-TOF-MS analysis, the peptides were reconstituted in $500 \mu \mathrm{L}$ FA and filtered $(0.45 \mu \mathrm{m}$; wwPTFE).

\section{Discovery driven LC-MS/MS analysis}

A Sciex TripleTOF 6600 mass spectrometer (Sciex, Darmstadt, Germany) connected to a Shimadzu Nexera X2 system (Shimadzu, Kyoto, Japan) operating in the positive electrospray ionization (ESI) mode was used for UHPLC-TOF-MS analysis. Control of the instrument and data acquisition were performed using AnalystTF software (version 1.7.1, Sciex). The chromatography system consisted of a $150 \times 2.1 \mathrm{~mm}$, 1.6 $\mu \mathrm{m}$ BioZen Peptide PS-C-18 LC column (Phenomenex, Aschaffenburg, Germany) equipped with a security guard ultra-column $(2 \times 2.1 \mathrm{~mm})$ of the same type. The injection volume was $10 \mu \mathrm{L}$ and the temperature of the column oven was set to $40{ }^{\circ} \mathrm{C}$. The elution solvents were (A) $1 \%$ (v/v) aqueous FA and (B) acetonitrile containing 1\% (v/v) FA.
A 75 min gradient was used to separate the peptides with a flow rate of $0.35 \mathrm{~mL} / \mathrm{min}$ starting at $0 \mathrm{~min}, 5 \% \mathrm{~B} ; 5 \mathrm{~min}$, 5\% B; $60 \mathrm{~min}, 40 \% \mathrm{~B} ; 65 \mathrm{~min}, 100 \% \mathrm{~B} ; 69 \mathrm{~min}, 100 \% \mathrm{~B}$; $70 \mathrm{~min}, 5 \% \mathrm{~B}$; and $75 \mathrm{~min}, 5 \% \mathrm{~B}$. The following parameters were set: ion spray voltage: $5500 \mathrm{eV}$, source temperature: $550^{\circ} \mathrm{C}$, nebulizing gas: 55 psi, heating gas: 65 psi and nitrogen as curtain gas: 35 psi.

A TOF-MS survey scan was acquired in the informationdependent acquisition mode (IDA), from $\mathrm{m} / \mathrm{z}, 400$ to 1000 using $250 \mathrm{~ms}$ as accumulation time, $10 \mathrm{~V}$ as collision energy (CE) and $80 \mathrm{~V}$ as declustering potential (DP). Product ion spectra were recorded in the high-resolution mode for $70 \mathrm{~ms}$ for the 12 most abundant compounds. The $\mathrm{m} / \mathrm{z}$ range was $m / z, 100-2000$ using a DP of $80 \mathrm{~V}$ and CE of $40 \mathrm{~V}$, with CE spread of $15 \mathrm{~V}$. IDA criteria were set for the precursor ion intensity at $>100$ counts/s. Q1 resolution was set to $0.7 \mathrm{Da}$.

\section{Identification of amylases using MaxQuant}

TOF raw files were used for the identification and relative quantitation of proteins using MaxQuant (version 1.6.10.43) [22]. A workflow with different searches against databases derived from UniProtKB using the search engine Andromeda was developed [23]. The first step of data evaluation comprised the identification of enzymes from the class EC 3.2.-.- (glycosylases). A database with all proteins belonging to the class EC 3.2.-.- from Triticum aestivum and from 14 microorganisms relevant for the production of food grade amylases according to EFSA and FDA was built [24, 25]. This database contained 5550 proteins (downloaded from UniProtKB on July 01, 2019). In the second step, all proteins present in the sample were identified, using databases containing the proteome of the identified organisms, respectively. In the final step, the relative quantitation of the proteins was performed using the intensity based absolute quantitation (iBAQ) algorithm implemented within MaxQuant [26]. For each sample, an individual database was built containing all proteins identified in the second step. A total sum normalization of iBAQ protein intensities between samples was performed to correct for the different total protein injection amounts.

The MaxQuant parameters were set as follows for all searches: Variable modifications: oxidation of methionine, $\mathrm{N}$-terminal protein acetylation; fixed modification: carbamidomethylation on cysteine; proteolytic enzyme: trypsin; missed cleavage sites: up to two. Match-between-runs was enabled with a matching time window of $0.7 \mathrm{~min}$ and an alignment time window of $20 \mathrm{~min}$. Results were filtered for a minimal length of five, a maximal length of 50 amino acids and $1 \%$ peptide and protein false discovery rate.

The content of amylase $[\mathrm{mg} / \mathrm{g}]$ present in the preparations added in the baking experiments, respectively, was calculated based on the protein contents of the amylase extracts 
for UHPLC-TOF-MS analysis considering the percentage of amylase determined via iBAQ. Thus, the absolute protein content in the sample was multiplied with the relative iBAQ value for each amylase.

\section{Baking experiments}

The recipe for the baking experiments was: Wheat flour type 550 ( $50 \mathrm{~g}$, based on $14 \%$ moisture), $2.0 \mathrm{~g}$ baking soda, $0.25 \mathrm{~g}$ sodium chloride and bulk liquid as determined in the Farinograph-E [27]. Water as bulk liquid was replaced by a buffer solution with $0.1 \mathrm{~mol} / \mathrm{L}$ citric acid monohydrate and $0.1 \mathrm{~mol} / \mathrm{L}$ trisodium citrate dihydrate $(\mathrm{pH} 2.75)$ to obtain a $\mathrm{pH}$ comparable to yeast-leavened wheat bread (pH 6). Baking soda was added $1 \mathrm{~min}$ before the end of the kneading time. The dough was kneaded at $60 \mathrm{rpm}$ to optimum consistency in the Farinograph-E [27]. After kneading, the dough was rounded for eight cycles and placed in the proofing cabinet for $20 \mathrm{~min}$ at $30{ }^{\circ} \mathrm{C}$ in a water-saturated atmosphere. Then the dough piece was rolled (roll gap: $0.8 \mathrm{~cm}$ ), folded in half, rounded for five cycles, and put into an aluminium baking pan for the second dough rest for 40 min under the same conditions as before. Baking took place in a deck oven Type-9110-0082 (Binder, Tuttlingen, Germany) at $230{ }^{\circ} \mathrm{C}$ for $18 \mathrm{~min}$.

The breads were either analysed after cooling ( 2 h) or they were stored at $22{ }^{\circ} \mathrm{C}$ under vacuum until further analysis. Amylase activity was determined after a storage time of $30 \mathrm{~h}$. To identify and quantitate sugars in the samples they were either extracted directly after cooling $(2 \mathrm{~h})$ or after storage for $22 \mathrm{~h}, 48 \mathrm{~h}$ and $96 \mathrm{~h}$ at $22{ }^{\circ} \mathrm{C}$. The baking experiments were carried out with four replicates.

\section{Quantitation of mono-, di-, and oligosaccharides in wheat bread crumb}

Mono-, di- and oligosaccharides were extracted from a sample taken from the centre of the bread crumb $(0.5 \mathrm{~g}$ of dry matter) using $4.0 \mathrm{~mL}$ of $50 \%(\mathrm{v} / \mathrm{v})$ methanol while stirring for $30 \mathrm{~min}$ at $22{ }^{\circ} \mathrm{C}$ followed by centrifugation at $3500 \times g$ and $20{ }^{\circ} \mathrm{C}$ for $20 \mathrm{~min}$. The solvent was removed using a rotary vacuum concentrator $\left(37^{\circ} \mathrm{C}, 9 \mathrm{~h}, 800 \mathrm{~Pa}\right)$. The dry samples were reconstituted in $1.0 \mathrm{~mL}$ deionized water and clean-up was performed using strong cation exchange columns (StrataX-C $33 \mu \mathrm{m}, 200 \mathrm{mg}, 3 \mathrm{~mL}$, Phenomenex). The columns were activated with methanol $(1 \times 3.0 \mathrm{~mL})$ and washed with $0.1 \%(\mathrm{v} / \mathrm{v})$ FA $(3 \times 3.0 \mathrm{~mL})$. After loading the sample, the sugars were eluted with $0.1 \%(\mathrm{v} / \mathrm{v})$ FA $(2 \times 2.0 \mathrm{~mL})$. The eluent was removed using a rotary vacuum concentrator $\left(37^{\circ} \mathrm{C}, 9 \mathrm{~h}, 800 \mathrm{~Pa}\right)$ and the sugars were redissolved in deionized water for further analysis.

Mono-, di- and oligosaccharides were analysed by highperformance anion exchange chromatography with pulsed amperometric detection (HPAEC-PAD) on a Dionex ICS5000 system (Thermo Fisher Scientific). The HPAEC-PAD system was equipped with a CarboPac PA 100 column $(250 \times 4 \mathrm{~mm})$ connected to a CarboPac PA 100 guard column $(50 \times 4 \mathrm{~mm})$. Elution was performed with $1.0 \mathrm{~mol} / \mathrm{L}$ sodium acetate solution (solvent $\mathrm{A}$ ), $1.0 \mathrm{~mol} / \mathrm{L}$ sodium hydroxide solution (solvent B) and deionized water (solvent C) at a flow rate of $1.0 \mathrm{~mL} / \mathrm{min}$. Solvent $B$ was set to $15 \%$ for the total run time. The gradient was $0 \mathrm{~min}, 0.5 \% \mathrm{~A}$; $2 \mathrm{~min}, 0.5 \% \mathrm{~A} ; 8 \mathrm{~min}, 10 \% \mathrm{~A} ; 18 \mathrm{~min}, 20 \% \mathrm{~A} ; 23 \mathrm{~min}, 20 \%$ A; $24 \mathrm{~min}, 0.5 \%$ A; $39 \mathrm{~min}, 0.5 \%$ A. PAD detection was carried out with a gold working electrode operating with a standard quadruple waveform. Chromeleon software 7.2 (Thermo Fisher Scientific) was used for system control and data analysis. Quantitation of the sugars was performed by means of external calibration with standard solutions.

\section{Statistical analysis}

The sugar contents of the breads containing one amylase preparation each are presented as mean value \pm standard deviation. Linear mixed models were used to explore possible differences of the sugar contents between the time points ( $2 \mathrm{~h}, 22 \mathrm{~h}, 48 \mathrm{~h}$ and $96 \mathrm{~h}$ after baking). The Bonferroni correction was applied to account for multiple testing. Statistical analyses were performed with $\mathrm{R}$ statistical software, version 3.6.1. (R Core Team, Vienna, Austria).

\section{Results}

\section{Identification of amylases and the protein composition of the preparations}

One maltotetraogenic amylase from $P$. saccharophila (UniProtKB accession P22963) was identified in preparations (I) and (II), respectively. In addition, an $\alpha$-amylase (D9J2M5) was identified in preparation (II). All maltogenic $\alpha$-amylase preparations (III)-(VII) contained P19531, a maltogenic $\alpha$-amylase from $G$. stearothermophilus and no additional amylolytic enzyme was detected (Table 2).

The composition of the preparations is shown in Figs. 1 and 2. Comparing the relative iBAQ values for preparation (I), the amylase P22963 accounted for the largest share (87.8\%) of all proteins, followed by $7.5 \%$ of proteins from Bacillus licheniformis and $2.1 \%$ of other proteins from $P$. saccharophila. In preparation (II), the major proportion of $71.1 \%$ was P22963 followed by other $P$. saccharophila proteins with $12.4 \%$. The $\alpha$-amylase D9J2M5 from Aspergillus oryzae accounted for $1.6 \%$ whereas other Aspergillus oryzae proteins were present with $4.4 \%$. Preparations (I) and (II) additionally contained other wheat proteins $[2.6 \%$ for (I) and $10.5 \%$ for (II)]. 
Table 2 Amylases identified in the preparations with their UniprotKB accession number, the number of peptides identified per amylase, the corresponding protein coverage and the organism to which the amylase was assigned

\begin{tabular}{llllll}
\hline Preparation & Protein & Enzyme & $\begin{array}{l}\text { No. of } \\
\text { peptides }\end{array}$ & Coverage (\%) & Organism \\
\hline (I) & P22963 & EC 3.2.1.60 & 25 & 29.6 & Pelomonas saccharophila \\
(II) & P22963 & EC 3.2.1.60 & 16 & 23.0 & Pelomonas saccharophila \\
& D9J2M5 & EC 3.2.1.1 & 16 & 35.7 & Aspergillus oryzae \\
(III) & P19531 & EC 3.2.1.133 & 31 & 61.5 & Geobacillus stearothermophilus \\
(IV) & P19531 & EC 3.2.1.133 & 49 & 60.8 & Geobacillus stearothermophilus \\
(V) & P19531 & EC 3.2.1.133 & 44 & 53.0 & Geobacillus stearothermophilus \\
(VI) & P19531 & EC 3.2.1.133 & 31 & 49.4 & Geobacillus stearothermophilus \\
(VII) & P19531 & EC 3.2.1.133 & 38 & 60.5 & Geobacillus stearothermophilus \\
\hline
\end{tabular}

All protein scores were $>150$
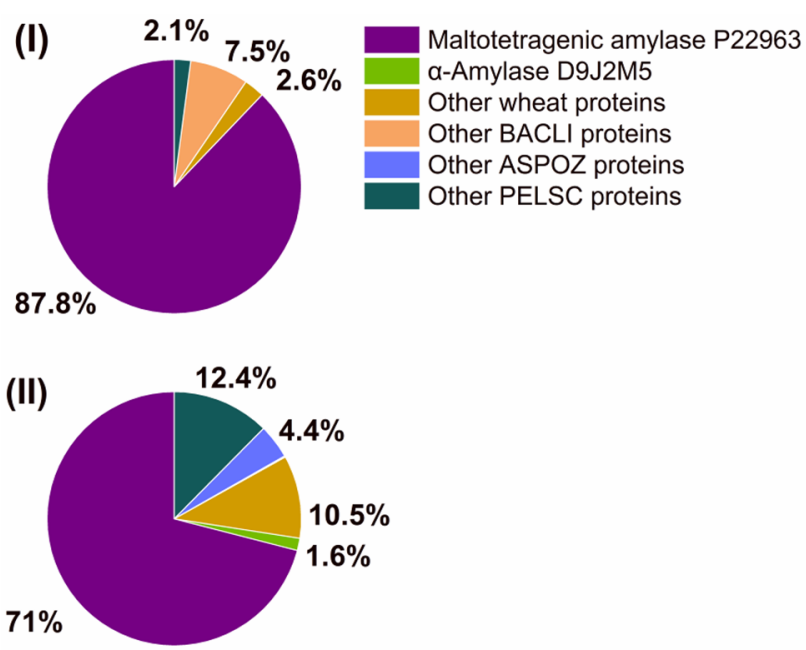

Fig. 1 Relative distribution of wheat and microbial proteins in the maltotetraogenic amylase preparations based on MaxQuant iBAQ values. (I) and (II) are Pelomonas saccharophila (PELSC) maltotetraogenic amylase preparations. Other microbial proteins detected are from Bacillus licheniformis (BACLI) and Aspergillus oryzae (ASPOZ)

All maltogenic $\alpha$-amylase preparations (Fig. 2) contained P19531 with a share of $\geq 90 \%$ [(IV) and (VII)), about $50 \%$ ((V) and (VI)] or comparably low with $5.4 \%$ (III). Preparations (IV) and (VII) contained exclusively proteins from $G$. stearothermophilus. Only preparations (III) and (VI) contained wheat proteins besides P19531 and other G. stearothermophilus proteins. Preparation (III) contained 53.4\% gluten and $41.2 \%$ other wheat proteins and preparation (VI) $22.8 \%$ gluten proteins and $30.8 \%$ other wheat proteins. Preparation (V) contained $34.9 \%$ proteins from Bacillus atrophaeus.

Based on the iBAQ values, the quantity of P22963 from $P$. saccharophila added in the baking experiments was $0.32 \mathrm{mg}$ for preparation (I) and $0.05 \mathrm{mg}$ for (II). Accordingly, the absolute amount of P19531 from the maltogenic $\alpha$-amylase preparations in the baking recipe ranged from $0.01 \mathrm{mg}$ (III) to $1.21 \mathrm{mg}$ (VII).

\section{Composition of mono-, di-, and oligosaccharides in bread without amylase addition}

The composition of mono-, di-, and oligosaccharides in bread crumb without addition of exogenous amylases (control) was already reported by Rebholz et al. [21]. The contents were as follows, sorted in descending order: maltose: $14.6 \mathrm{mg} / \mathrm{g}_{\mathrm{dm}}( \pm 1.1)$, sucrose: $5.8 \mathrm{mg} / \mathrm{g}_{\mathrm{dm}}( \pm 0.8)$, glucose: $2.9 \mathrm{mg} / \mathrm{g}_{\mathrm{dm}}( \pm 0.6)$, fructose: $2.8 \mathrm{mg} / \mathrm{g}_{\mathrm{dm}}( \pm 2.0)$, maltotriose: $1.5 \mathrm{mg} / \mathrm{g}_{\mathrm{dm}}( \pm 0.1)$ and maltotetraose: $1.1 \mathrm{mg} / \mathrm{g}_{\mathrm{dm}}( \pm 0.3)$. No significant changes in the content of the detected sugars were detected during $48 \mathrm{~h}$ of storage.

\section{Composition of mono-, di-, and oligosaccharides in breads with amylase addition and changes during storage}

The total sugar content was $39.1 \mathrm{mg} / \mathrm{g}_{\mathrm{dm}}( \pm 3.8)$ for preparation (I) (Fig. 3) and $58.9 \mathrm{mg} / \mathrm{g}_{\mathrm{dm}}( \pm 5.4)$ for preparation (II) $2 \mathrm{~h}$ after baking (Fig. 4). The glucose content did not increase significantly from 2 to $22 \mathrm{~h}$, but increased significantly from 22 to $48 \mathrm{~h}\left[3.8 \mathrm{mg} / \mathrm{g}_{\mathrm{dm}}( \pm 0.3)\right.$ to $4.8 \mathrm{mg} / \mathrm{g}_{\mathrm{dm}}$ $( \pm 0.4)]$ in the bread containing preparation (I). The content of maltotriose increased significantly from $22 \mathrm{~h}[0.2 \mathrm{mg} /$ $\left.\mathrm{g}_{\mathrm{dm}}( \pm 0.2)\right]$ to $48 \mathrm{~h}\left[1.6 \mathrm{mg} / \mathrm{g}_{\mathrm{dm}}( \pm 0.5)\right]$, while the content of fructose, maltose and maltotetraose did not show significant changes from 2 to 48 h of storage. Glucose, fructose, sucrose, maltose, maltotriose and maltotetraose were detected $2 \mathrm{~h}$ after baking in the bread containing preparation (II). In contrast to preparation (I), maltopentaose, maltohexaose, maltoheptaose and maltooctaose were additionally detected in the bread crumb after $48 \mathrm{~h}$. The maltotetraose content increased significantly from $2.1 \mathrm{mg} / \mathrm{g}_{\mathrm{dm}}( \pm 1.7)$ to $29.5 \mathrm{mg} / \mathrm{g}_{\mathrm{dm}}( \pm 2.0)$, so that it was the main sugar in the bread manufactured with (II) $96 \mathrm{~h}$ after baking. 
Fig. 2 Relative distribution of wheat and microbial proteins in the maltogenic $\alpha$-amylase preparations based on MaxQuant iBAQ values. All preparations contain the maltogenic $\alpha$-amylase from Geobacillus stearothermophilus (GEOSE). Other microbial proteins detected are from Bacillus atrophaeus (BACAT)
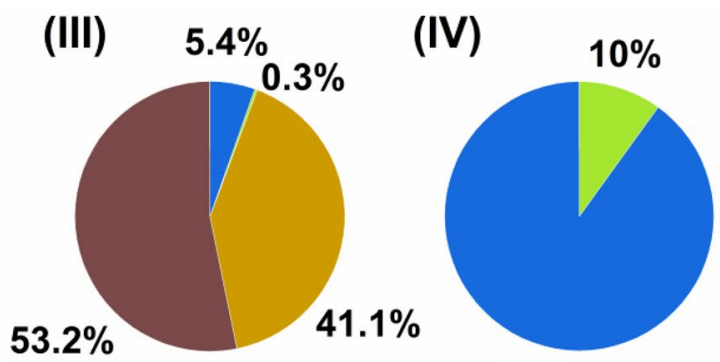

Gluten proteins

Other wheat proteins

Other GEOSE proteins

Maltogenic a-amylase P19531

Other BACAT proteins

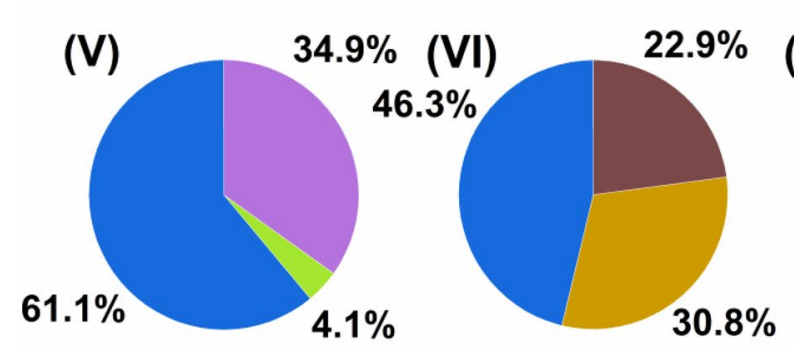

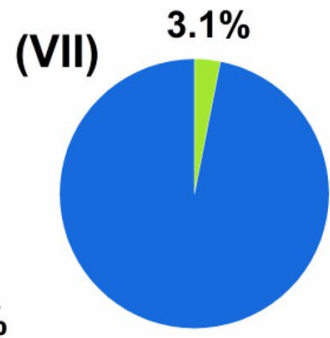

$96.9 \%$
Fig. 3 Sugar content of model breads manufactured with addition of (I), maltotetraogenic amylase preparation from Pelomonas saccharophila. Samples were taken $2 \mathrm{~h}, 22 \mathrm{~h}$, and $48 \mathrm{~h}$ after baking. Values are displayed as means \pm standard deviation $(n=4)$. Different letters represent significant differences in content for each sugar, respectively $(p<0.05)$

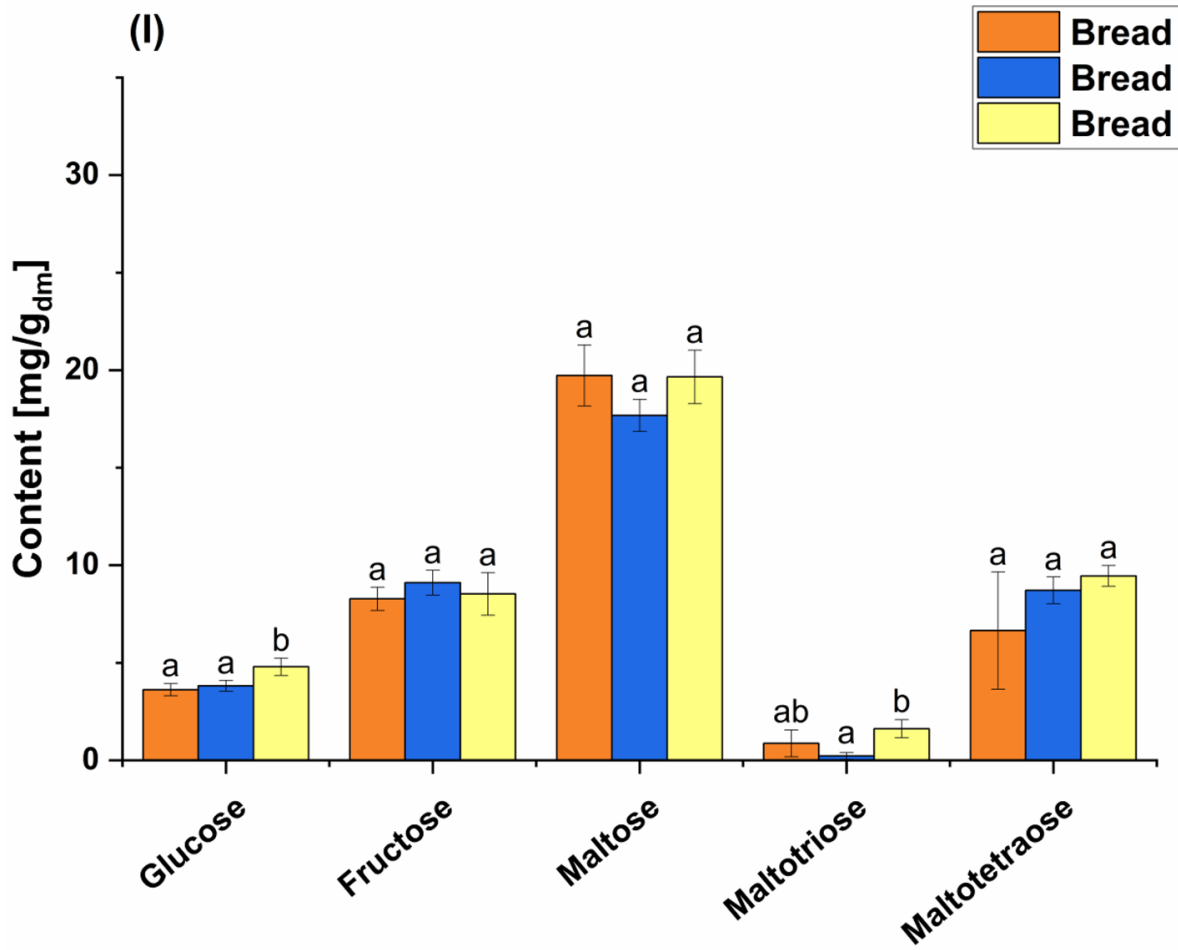

Glucose, fructose, sucrose, maltose, maltotriose and maltotetraose were identified $2 \mathrm{~h}$ after baking in all breads manufactured with exogenous maltogenic $\alpha$-amylase (Figs. 5, 6), except for breads with (IV) where maltotetraose was identified for the first time at $22 \mathrm{~h}$ after baking. Additionally, maltopentaose was detected after $48 \mathrm{~h}$ and maltohexaose after $96 \mathrm{~h}$ of storage in the samples containing preparation
(VI). The total sugar content ranged from $55.3 \mathrm{mg} / \mathrm{g}_{\mathrm{dm}}$ $( \pm 4.4)(\mathrm{V})$ to $108.4 \mathrm{mg} / \mathrm{g}_{\mathrm{dm}}( \pm 1.6)(\mathrm{VI})$ after $2 \mathrm{~h}$. Maltose contents ranged from $25.3 \mathrm{mg} / \mathrm{g}_{\mathrm{dm}}( \pm 1.9)$ for $(\mathrm{V})$ to $50.0 \mathrm{mg} / \mathrm{g}_{\mathrm{dm}}( \pm 4.4)$ for (VII) $2 \mathrm{~h}$ after baking. No significant increase in maltose content was detected between 2 and $96 \mathrm{~h}$ in the breads manufactured with (III) and (VII). For preparation (IV), the maltose content increased significantly 
Fig. 4 Sugar content of model breads manufactured with addition of (II), maltotetraogenic amylase preparation from Pelomonas saccharophila. Samples were taken $2 \mathrm{~h}, 22 \mathrm{~h}, 48 \mathrm{~h}$, and $96 \mathrm{~h}$ after baking. Values are displayed as means \pm standard deviation $(n=4)$. Different letters represent significant differences in content for each sugar, respectively $(p<0.05)$

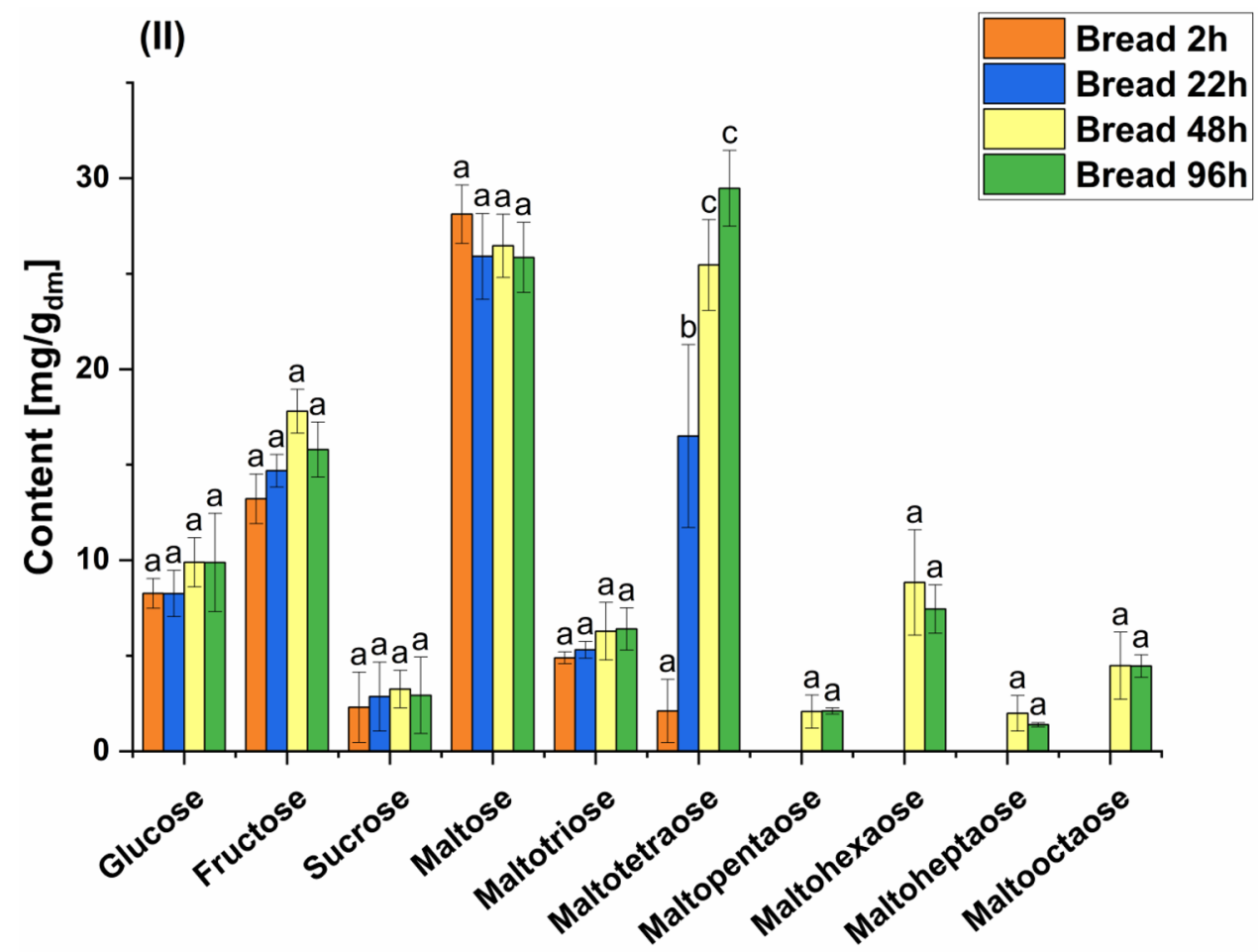

from $27.7 \mathrm{mg} / \mathrm{g}_{\mathrm{dm}}( \pm 0.8)$ up to $38.8 \mathrm{mg} / \mathrm{g}_{\mathrm{dm}}( \pm 8.6)$, for $(\mathrm{V})$ from $25.3 \mathrm{mg} / \mathrm{g}_{\mathrm{dm}}( \pm 1.9)$ to $40.4 \mathrm{mg} / \mathrm{g}_{\mathrm{dm}}( \pm 0.7)$ and for $(\mathrm{VI})$ from $37.0 \mathrm{mg} / \mathrm{g}_{\mathrm{dm}}( \pm 3.2)$ to $68.6 \mathrm{mg} / \mathrm{g}_{\mathrm{dm}}( \pm 4.9)$ considering $2 \mathrm{~h}$ and $96 \mathrm{~h}$ of storage. The maltotetraose content of the bread crumbs containing preparations (V), (VI) and (VII) increased significantly between 2 and $96 \mathrm{~h}$ of storage. The increase was from $5.9 \mathrm{mg} / \mathrm{g}_{\mathrm{dm}}( \pm 3.9)$ to $11.9 \mathrm{mg} / \mathrm{g}_{\mathrm{dm}}( \pm 2.2)$ for $(V)$, from $9.7 \mathrm{mg} / \mathrm{g}_{\mathrm{dm}}( \pm 1.7)$ to $44.1 \mathrm{mg} / \mathrm{g}_{\mathrm{dm}}( \pm 6.6)$ for (VI) and from $0.6 \mathrm{mg} / \mathrm{g}_{\mathrm{dm}}( \pm 0.2)$ to $22.9 \mathrm{mg} / \mathrm{g}_{\mathrm{dm}}( \pm 9.3)$ for (VII). No significant changes in the content of sucrose were observed during storage of the breads containing either of the maltogenic $\alpha$-amylase preparations.

\section{Residual activity of amylases in model wheat bread}

The endogenous activity of the wheat flour used for the baking experiments was $4.1 \mathrm{nkat} / \mathrm{g}_{\mathrm{dm}}( \pm 0.7)$ for $\alpha$-amylase and $378.4 \mathrm{nkat} / \mathrm{g}_{\mathrm{dm}}( \pm 6.1)$ for $\beta$-amylase. As we have shown before, no cereal amylase activity was detected in the crumb of the control breads after baking [21].

For the maltotetraogenic amylase preparation, (I) we detected $85.8 \mathrm{nkat} / \mathrm{g}_{\mathrm{dm}}( \pm 11.6)$ and for preparation (II) $31.7 \mathrm{nkat} / \mathrm{g}_{\mathrm{dm}}( \pm 6.6)$. After baking, the residual amylase activity was $0.9 \mathrm{nkat} / \mathrm{g}_{\mathrm{dm}}( \pm 0.3)$ in (I) and $0.6 \mathrm{nkat} / \mathrm{g}_{\mathrm{dm}}$ $( \pm 0.2)$ in (II). This corresponds to a relative residual activity of $1.1 \%$ for (I) and $1.9 \%$ for (II) compared to the amylase activity originally used in the dough (Table 1). The activity of maltogenic $\alpha$-amylase preparations applied to the dough was between $22.0 \mathrm{nkat} / \mathrm{g}_{\mathrm{dm}}( \pm 0.7)$ for preparation (III) and
$42.9 \mathrm{nkat} / \mathrm{g}_{\mathrm{dm}}( \pm 2.0)$. All tested maltogenic $\alpha$-amylase preparations showed a residual amylase activity (Table 1). Based on the absolute values, the residual activity was between $5.7 \mathrm{nkat} / \mathrm{g}_{\mathrm{dm}}( \pm 1.2)$ for $(\mathrm{VII})$ and $14.3 \mathrm{nkat} / \mathrm{g}_{\mathrm{dm}}( \pm 3.8)$ for (VI). Compared to the activities applied to the doughs, the relative residual amylase activity in the breads ranged from $13.9 \%$ in the breads with (VII) to $45.5 \%$ for (VI).

\section{Discussion}

In this study, we combined discovery-driven proteomics with the quantitation of mono-, di- and oligosaccharides in bread crumb and the determination of residual amylase activity to get insights into changes in sugar composition caused by the action of exogenous maltotetraogenic amylases and maltogenic $\alpha$-amylases during straight dough wheat bread making and storage.

For the group of maltotetraogenic amylase and the group of maltogenic $\alpha$-amylase preparations, one amylase each was identified as being responsible for the amylolytic activity. Our results are in accordance with Prandi et al. who also identified P19531, a maltogenic $\alpha$-amylase from $G$. stearothermophilus, as being responsible for the amylolytic activity in maltogenic $\alpha$-amylase preparations applied in baking [28]. To the best of our knowledge, we are the first to analyze maltotetraogenic amylase preparations with proteomics tools and we identified a single amylase P22963 as cause of the amylolytic activity. The iBAQ evaluation was 

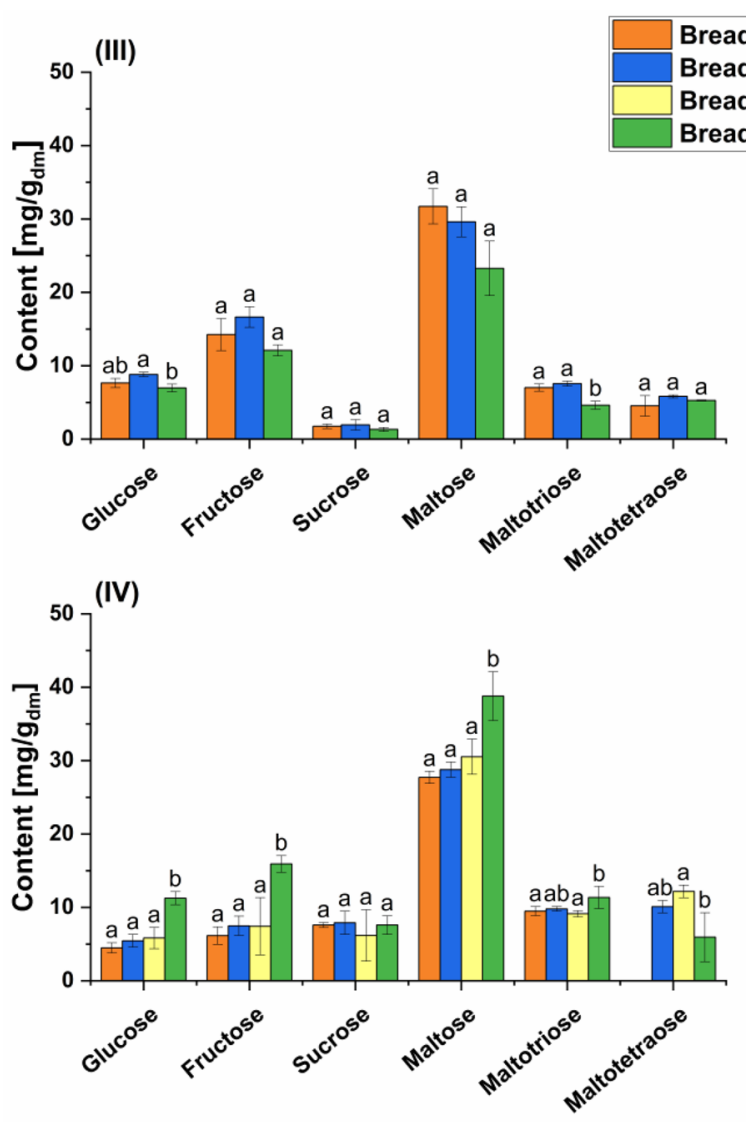

aread $2 h$

Bread 96h

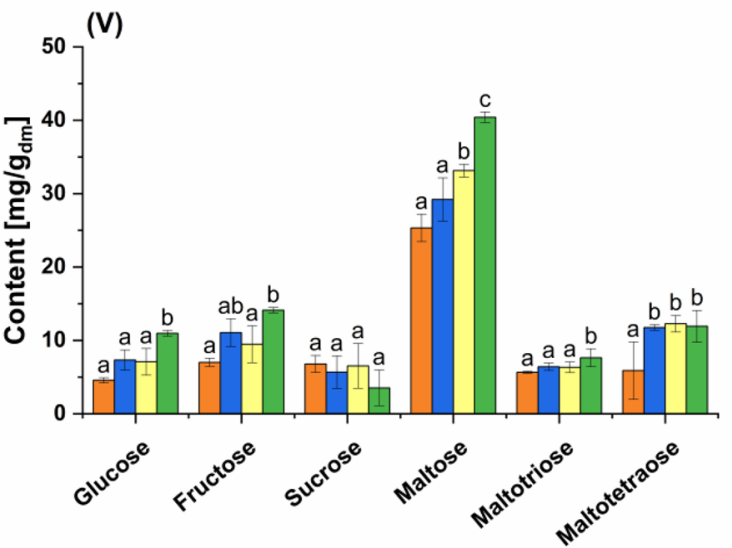

Fig. 5 Sugar content of model breads manufactured with addition of maltogenic $\alpha$-amylase preparations from Geobacillus stearothermophilus (III), (IV) and (V). Samples were taken 2 h, 22 h, 48 h, and $96 \mathrm{~h}$ after baking. Values are displayed as means \pm standard deviation $(n=4)$. Different letters represent significant differences in content for each sugar, respectively $(p<0.05)$

shown to be suitable for the relative quantitation of several different proteins in one sample [26, 29]. The proportion of maltotetraogenic amylase in the preparations (I) and (II) was $87.8 \%$ and $71.0 \%$, respectively. Both preparations also contained $4-7 \%$ of proteins from other microorganisms and non-gluten proteins, such as the starch synthases P27736 and Q8W2G8, indicating that wheat starch was used as a

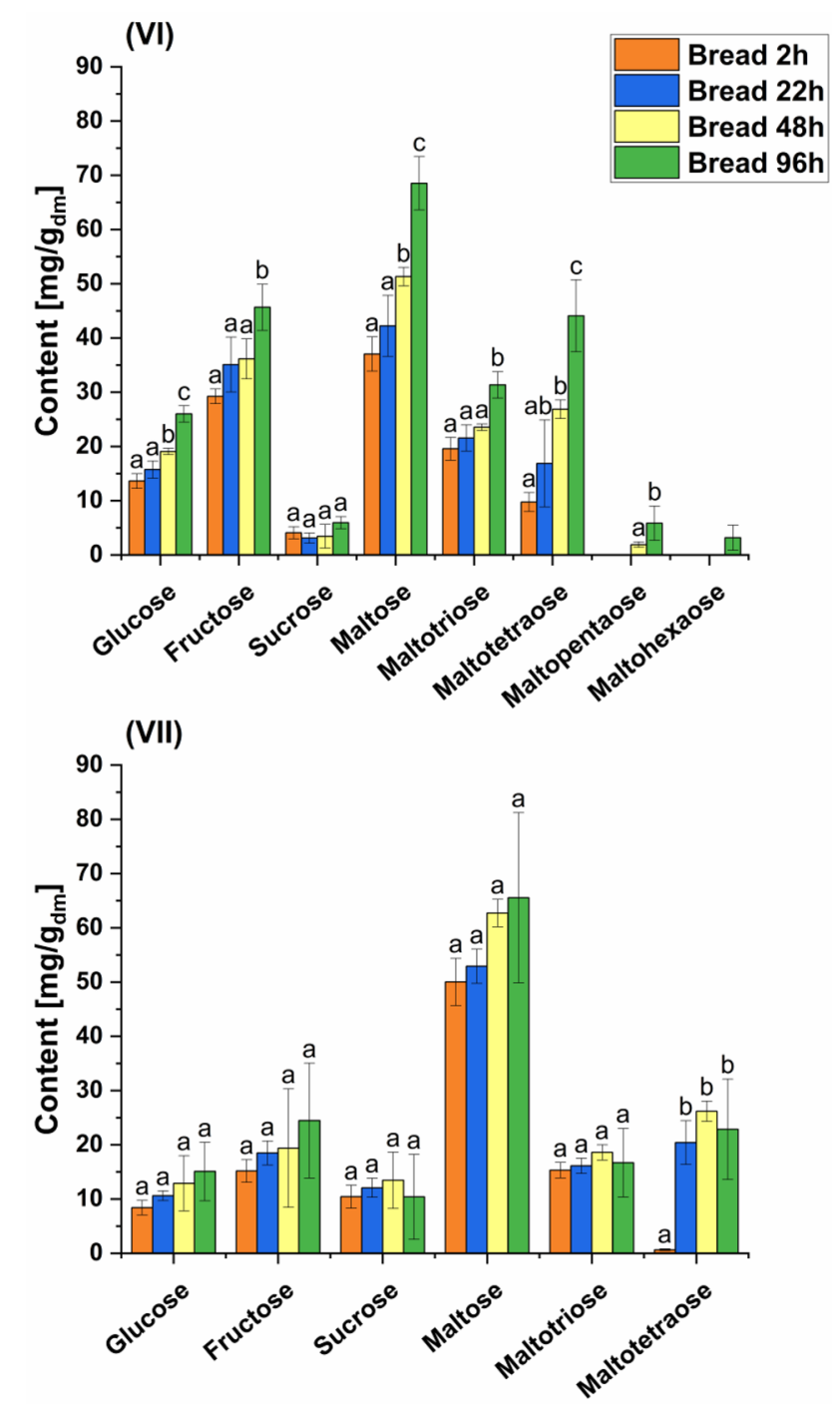

Fig. 6 Sugar content of model breads manufactured with addition of maltogenic $\alpha$-amylase preparations from Geobacillus stearothermophilus (VI) and (VII). Samples were taken 2 h, 22 h, 48 h, and 96 h after baking. Values are displayed as means \pm standard deviation $(n=4)$. Different letters represent significant differences in content for each sugar, respectively $(p<0.05)$

filler material [30]. The maltogenic $\alpha$-amylase preparations showed large differences in composition considering that the percentage of maltogenic $\alpha$-amylase ranged from $5.4 \%$ (III) up to $96.9 \%$ (VII).

Although both groups of preparations, maltotetraogenic amylase and maltogenic $\alpha$-amylase, contained the same active enzyme, respectively, the effects on the sugar composition of the bread crumb were quite different. A higher initial activity applied to the dough resulted in a higher maltotetraose content in the bread crumb using the maltotetraogenic amylase preparations (I) and (II). The activity applied to the dough of (I) was $85.8 \mathrm{nkat} / \mathrm{g}_{\mathrm{dm}}$ and $171 \%$ higher than the activity of (II) with $31.7 \mathrm{nkat} / \mathrm{g}_{\mathrm{dm}}$. Corresponding to that, 
the content of the main reaction product, maltotetraose, was about $219 \%$ higher with a mean of $6.7 \mathrm{mg} / \mathrm{g}_{\mathrm{dm}}$ (I) compared to $2.2 \mathrm{mg} / \mathrm{g}_{\mathrm{dm}}$ (II) $2 \mathrm{~h}$ after baking. A similar result was described by Bae et al. when using Pseudomonas saccharophila maltotetraogenic amylase. An increase of $200 \%$ of maltotetraogenic amylase activity in whole wheat bread making resulted in an increase of $145 \%$ of maltotetraose in their study [31].

Overall, only minor changes in the sugar composition were detected during the $48 \mathrm{~h}$ of storage of the breads containing preparation (I) and especially no changes in maltotetraose content. This agrees well with the results of Bosmans et al. [8] who also observed no significant changes in the content of maltooligosaccharides in wheat bread during storage using Pseudomonas saccharophila maltotetraogenic amylase. Bosmans et al. [8] and Derde et al. [9, 14] assumed inactivation of the maltotetraogenic amylase during baking. We detected a very low residual activity $(1.1 \%$ of the applied activity) for (I), but apparently this did not cause major changes in the sugar composition of the bread during storage. Opposed to that, the residual activity of (II) was also very low (1.9\%), but the absolute maltotetraose content increased from $2.1 \mathrm{mg} / \mathrm{g}_{\mathrm{dm}} 2 \mathrm{~h}$ after baking up to $29.5 \mathrm{mg} /$ $\mathrm{g}_{\mathrm{dm}}$ after $96 \mathrm{~h}$. Thus, maltotetraose increased by $1112 \%$ during $48 \mathrm{~h}$ and $1300 \%$ during $96 \mathrm{~h}$ of storage. An additional effect was the formation of maltopentaose, maltohexaose, maltoheptaose and maltooctaose after $48 \mathrm{~h}$ and $96 \mathrm{~h}$. These sugars were not present up until $22 \mathrm{~h}$ of storage and could be products caused by endohydrolysis of starch chains [9].

Besides its exo-action on starch molecules, G. stearothermophilus maltogenic $\alpha$-amylase performs various endoattacks on starch [9], with maltose and higher maltooligosaccharides as main products $[8,32]$. Our study also confirmed these findings, because the content of maltose and maltooligosaccharides $\left(40.0 \mathrm{mg} / \mathrm{g}_{\mathrm{dm}}\right.$ for $(\mathrm{V})$ to $66.0 \mathrm{mg} / \mathrm{g}_{\mathrm{dm}}$ for (VII)) was higher in all breads with maltogenic $\alpha$-amylase preparations $2 \mathrm{~h}$ after baking compared to the control bread $\left(17.3 \mathrm{mg} / \mathrm{g}_{\mathrm{dm}}\right)$. In addition, preparation (VI) caused the formation of maltopentaose and maltohexaose, which were not detected in the control. It is also known that maltogenic $\alpha$-amylase can release glucose from amylose and amylopectin [32]. Therefore, the significant increase of glucose in breads made with the preparations (IV), (V), and (VI) could be a possible consequence of the residual activity.

The main action of maltogenic $\alpha$-amylase on starch takes place during bread baking, but changes in maltose content during cooling and storage have also been reported for wheat bread $[8,15]$. We observed significant changes for maltose and higher maltooligosaccharides for all maltogenic $\alpha$-amylase preparations during storage (Figs. 5, 6), but these changes were not always the same. There was no direct correlation between the level of residual activity and the amount of sugars formed during storage for the breads made with of maltogenic $\alpha$-amylase. Using preparation (IV), maltotetraose was identified for the first time at $22 \mathrm{~h}$, whereas(VI) showed the largest impact on the sugar spectrum of wheat bread compared to the control, including the release of maltooligosaccharides after $96 \mathrm{~h}$. In contrast, no significant increase in the sugar concentrations was determined for the breads made with preparation (III), although a residual activity of $42.3 \%$ was detected. The absolute contents of maltogenic $\alpha$-amylase added in the baking experiments ranged from $0.01 \mathrm{mg}$ (III) to $1.21 \mathrm{mg}$ (VII), but there was no direct correlation between the content and the residual activity. This might be due to differences inherent in the preparations we used and could be studied using various dosages of each preparation. However, the intent of our study was not to provide a detailed comparison of the different preparations, but rather show how sugar concentrations are affected when using each preparation at the recommended dosage.

Considering the applied activities in bread dough (Table 1), the relative residual maltogenic $\alpha$-amylase activities were between $13.9 \%$ for (VII) and $45.5 \%$ for (VI) and are likely to be responsible for the changes in mono-, di- and oligosaccharide content observed during $96 \mathrm{~h}$ of storage. Reichenberger et al. found a comparable relative residual activity of $17.8 \%$ for maltogenic $\alpha$-amylase in their wheat baking experiment [16]. Whether the detected residual activity is related to the characteristics of bread staling or bread crumb properties must be clarified in further studies. We showed that measurements of residual enzymatic activities alone cannot provide sufficient information to evaluate a potential technological function in the final product.

\section{Conclusion}

In this study, we identified the specific amylases in two maltotetraogenic amylase and five maltogenic $\alpha$-amylase preparations commonly applied in wheat bread making. Due to their high temperature stability, a low to medium residual amylolytic activity was found in the bread crumbs containing each of the preparations. Significant changes for glucose, maltose, and higher maltooligosaccharides were observed during storage for up to $96 \mathrm{~h}$ and these were most likely caused by the residual amylolytic activity. By applying a methodological approach which targets various amylases and enables the identification of the link between amylases, their residual activity and the resulting changes in the saccharide content of straight dough wheat bread, we provide the foundation for a better understanding of the residual activity of exogenous amylases in wheat bread making.

Acknowledgements The authors thank Stefanie Hackl and Angelika Grassl for excellent technical assistance, Dr. Sabrina Geisslitz (KIT) 
for helpful discussions and Dr. Leonie Weinhold (IMBIE, University Hospital Bonn) for advice on statistical evaluation.

Author contributions Conceptualization: GFR and KAS; methodology: GFR and KAS; formal analysis and investigation: GFR, KS and SD; writing — original draft and visualization: GFR; writing - review and editing: KS, SD, CD, TH, and KAS; resources: $\mathrm{CD}$ and TH; supervision and project administration: KAS.

Funding This IGF Project of the FEI was supported via AiF within the programme for promoting the Industrial Collective Research (IGF) of the German Ministry of Economic Affairs and Energy (BMWi), based on a resolution of the German Parliament. Allianz Industrie Forschung (Project AiF 19543N). Open access funding enabled and organized by Projekt DEAL.

\section{Declarations}

Conflict of interest The authors declare no competing financial interest.

Compliance with ethics requirements This article does not contain any studies with human or animal subjects.

Informed consent Not applicable.

Open Access This article is licensed under a Creative Commons Attribution 4.0 International License, which permits use, sharing, adaptation, distribution and reproduction in any medium or format, as long as you give appropriate credit to the original author(s) and the source, provide a link to the Creative Commons licence, and indicate if changes were made. The images or other third party material in this article are included in the article's Creative Commons licence, unless indicated otherwise in a credit line to the material. If material is not included in the article's Creative Commons licence and your intended use is not permitted by statutory regulation or exceeds the permitted use, you will need to obtain permission directly from the copyright holder. To view a copy of this licence, visit http://creativecommons.org/licenses/by/4.0/.

\section{References}

1. Gray JA, Bemiller JN (2003) Bread staling: molecular basis and control. Compr Rev Food Sci Food Saf. https://doi.org/10.1111/j. 1541-4337.2003.tb00011.x

2. Goesaert H, Slade L, Levine H, Delcour JA (2009) Amylases and bread firming —an integrated view. J Cereal Sci. https://doi.org/ 10.1016/j.jcs.2009.04.010

3. Bosmans GM, Lagrain B, Ooms N, Fierens E, Delcour JA (2013) Biopolymer interactions, water dynamics, and bread crumb firming. J Agric Food Chem. https://doi.org/10.1021/jf4010466

4. Ribotta PD, Le Bail A (2007) Thermo-physical assessment of bread during staling. LWT. https://doi.org/10.1016/j.lwt.2006.03. 023

5. Hug-Iten S, Fischer F, Conde-Petit B (2003) Staling of bread: role of amylose and amylopectin and influence of starch-degrading enzymes. Cereal Chem. https://doi.org/10.1094/CCHEM.2003. 80.6 .654

6. Hug-Iten S, Fischer F, Conde-Petit B (2001) Structural properties of starch in bread and bread model systems: influence of an antistaling alpha-amylase. Cereal Chem. https://doi.org/10.1094/ CCHEM.2001.78.4.421
7. Martin ML, Hoseney RC (1991) A Mechanism of bread firming. II. Role of starch hydrolyzing enzymes. Cereal Chem 68:503-507

8. Bosmans GM, Lagrain B, Fierens E, Delcour JA (2013) Impact of amylases on biopolymer dynamics during storage of straightdough wheat bread. J Agric Food Chem. https://doi.org/10.1021/ jf402021g

9. Derde LJ, Gomand SV, Courtin CM, Delcour JA (2012) Hydrolysis of $\beta$-limit dextrins by $\alpha$-amylases from porcine pancreas, Bacillus subtilis, Pseudomonas saccharophila and Bacillus stearothermophilus. Food Hydrocolloids. https://doi.org/10.1016/j.foodhyd. 2011.06.001

10. Goesaert H, Bijttebier A, Delcour JA (2010) Hydrolysis of amylopectin by amylolytic enzymes: level of inner chain attack as an important analytical differentiation criterion. Carbohydr Res. https://doi.org/10.1016/j.carres.2009.11.011

11. Goesaert H, Brijs K, Veraverbeke WS, Courtin CM, Gebruers K, Delcour JA (2005) Wheat flour constituents. How they impact bread quality, and how to impact their functionality. Trends Food Sci Technol. https://doi.org/10.1016/j.tifs.2004.02.011

12. Amigo JM, Del Olmo AA, Engelsen MM, Lundkvist H, Engelsen SB (2016) Staling of white wheat bread crumb and effect of maltogenic $\alpha$-amylases. Part 1 . Spatial distribution and kinetic modeling of hardness and resilience. Food Chem. https:// doi.org/10.1016/j.foodchem.2016.02.162

13. Goesaert H, Leman P, Bijttebier A, Delcour JA (2009) Antifirming effects of starch degrading enzymes in bread crumb. J Agric Food Chem. https://doi.org/10.1021/jf803058v

14. Derde LJ, Gomand SV, Courtin CM, Delcour JA (2012) Characterisation of three starch degrading enzymes: thermostable $\beta$-amylase, maltotetraogenic and maltogenic $\alpha$-amylases. Food Chem. https://doi.org/10.1016/j.foodchem.2012.05.031

15. Lagrain B, Leman P, Goesaert H, Delcour JA (2008) Impact of thermostable amylases during bread making on wheat bread crumb structure and texture. Food Res Int. https://doi.org/10. 1016/j.foodres.2008.07.006

16. Reichenberger K, Luz A, Seitl I, Fischer L (2020) Determination of the direct activity of the maltogenic amylase from Geobacillus stearothermophilus in white bread. Food Anal Methods. https://doi.org/10.1007/s12161-019-01673-7

17. European Parliament, European Council (2008) Regulation (EC) No 1332/2008 of the European Parliament and of the Council of 16 December 2008 on food enzymes and amending Council Directive 83/417/EEC, Council Regulation (EC) No 1493/1999, Directive 2000/13/EC, Council Directive 2001/112/EC and Regulation (EC) No 258/9

18. European Parliament, European Council Regulation (EU) No $1169 / 2011$ of the European Parliament and of the Council of 25 October 2011 on the provision of food information to consumers, amending Regulations (EC) No 1924/2006 and (EC) No $1925 / 2006$ of the European Parliament and of the Council, and repealing Commission Directive 87/250/EEC, Council Directive 90/496/EEC, Commission Directive 1999/10/EC, Directive 2000/13/EC of the European Parliament and of the Council, Commission Directives 2002/67/EC and 2008/5/EC and Commission Regulation (EC) No 608/2004

19. Cornaggia C, Evans DE, Draga A, Mangan D, McCleary BV (2019) Prediction of potential malt extract and beer filterability using conventional and novel malt assays. J Inst Brew. https:// doi.org/10.1002/jib.567

20. Uhr L, Buchholz T, Homann T, Huschek G, Rawel HM (2014) Targeted proteomics-based analysis of technical enzymes from fungal origin in baked products. J Cereal Sci. https://doi.org/10. 1016/j.jcs.2014.04.007

21. Rebholz GF, Sebald K, Dirndorfer S, Dawid C, Hofmann T, Scherf KA (2021) Impact of exogenous $\alpha$-amylases on sugar 
release on straight dough wheat bread. Eur Food Res Technol. https://doi.org/10.1007/s00217-020-03657-y

22. Cox J, Mann M (2008) MaxQuant enables high peptide identification rates, individualized ppb-range mass accuracies and proteome-wide protein quantification. Nat Biotechnol. https:// doi.org/10.1038/nbt.1511

23. Cox J, Neuhauser N, Michalski A, Scheltema RA, Olsen JV, Mann M (2011) Andromeda: a peptide search engine integrated into the MaxQuant environment. J Proteome Res. https://doi. org/10.1021/pr101065j

24. European Food Safety Authority, Parma, IT. https://www.efsa. europa.eu/de/search/site/amylase. Accessed 1 July 2019

25. Food and Drug Administration, Silver Spring, USA. https://www. search.usa.gov/search?query $=$ amylase $\&$ affiliate $=f d a 1$. Accessed 1 July 2019

26. Schwanhäusser B, Busse D, Li N, Dittmar G, Schuchhardt J, Wolf J, Chen W, Selbach M (2011) Global quantification of mammalian gene expression control. Nature. https://doi.org/10.1038/natur e10098

27. Kieffer R, Wieser H, Henderson MH, Graveland A (1998) Correlations of the breadmaking performance of wheat flour with rheological measurements on a micro-scale. J Cereal Sci. https:// doi.org/10.1006/jcrs.1997.0136

28. Prandi B, Lambertini F, Varani M, Faccini A, Suman M, Leporati A, Tedeschi T, Sforza S (2020) Assessment of enzymatic improvers in flours using LC-MS/MS detection of marker tryptic peptides. J Am Soc Mass Spectrom. https://doi.org/10.1021/jasms. 9b00109

29. Geisslitz S, Ludwig C, Scherf KA, Koehler P (2018) Targeted LC-MS/MS reveals similar contents of $\alpha$-amylase/trypsin-inhibitors as putative triggers of nonceliac gluten sensitivity in all wheat species except einkorn. J Agric Food Chem. https://doi.org/10. 1021/acs.jafc.8b04411

30. Ainsworth C, Clark J, Balsdon J (1993) Expression, organisation and structure of the genes encoding the waxy protein (granulebound starch synthase) in wheat. Plant Mol Biol. https://doi.org/ 10.1007/BF00038996

31. Bae W, Lee SH, Yoo S-H, Lee S (2014) Utilization of a maltotetraose-producing amylase as a whole wheat bread improver: dough rheology and baking performance. J Food Sci. https://doi. org/10.1111/1750-3841.12538

32. Christophersen C, Otzen D, Normann BE, Christiensen S, Schäfer T (1998) Enzymatic characterisation of Novamyl ${ }^{\circledR}$, a thermostable $\alpha$-amylase. Starke. https://doi.org/10.1002/(SICI)1521379X(199801)50:1\%3C39::AID-STAR39\%3E3.0.CO;2-S

Publisher's Note Springer Nature remains neutral with regard to jurisdictional claims in published maps and institutional affiliations. 